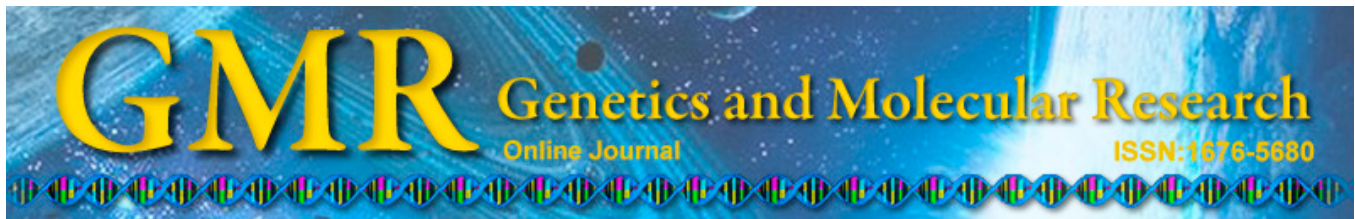

\title{
Isolation of new polymorphic microsatellite markers from the marbled rockfish Sebastiscus marmoratus
}

\author{
H.W. Deng ${ }^{1,2}$, Z.B. Li ${ }^{1,2}$, G. Dai ${ }^{1,2}$, Y. Yuan ${ }^{1,2}$, Y.F. Ning ${ }^{1,2}$, J.B. Shangguan ${ }^{1,2}$ \\ and Y.S. Huang ${ }^{1,2}$ \\ ${ }^{1}$ Fisheries College, Jimei University, Xiamen, China \\ ${ }^{2}$ Fujian Provincial Key Laboratory of Marine Fishery \\ Resources and Eco-Environment, Xiamen, China \\ Corresponding author: Z.B. Li \\ E-mail: lizhongbao@jmu.edu.cn
}

Genet. Mol. Res. 14 (1): 758-762 (2015)

Received January 6, 2014

Accepted September 6, 2014

Published January 30, 2015

DOI http://dx.doi.org/10.4238/2015.January.30.19

\begin{abstract}
The marbled rockfish, Sebastiscus marmoratus, is an important commercially near-shore fish that inhabits the beach rocky bottom from Japan to the South China Sea. Eleven polymorphic microsatellite loci were developed from $S$. marmoratus and were used to identify polymorphisms in 30 samples from a wild population. The allele locus number ranged from 2 to 7 . Polymorphism data content ranged from 0.032 to 0.751 . The observed and expected heterozygosity levels were $0.0333-0.9667$ and $0.0328-0.7675$, respectively. Two loci, Smd1-112 and Smd2-80, deviated from Hardy-Weinberg equilibrium. These polymorphic microsatellite markers will facilitate further studies of genetic diversity and genetic differentiation of S. marmoratus.
\end{abstract}

Key words: Genetic markers; Microsatellite; Sebastiscus marmoratus; Conservation resources 


\section{INTRODUCTION}

The marbled rockfish Sebastiscus marmoratus inhabits the littoral rocky bottom and is widely distributed in the East Sea and the South Sea of China, as well as from southern Japan to eastern Korea (Shen, 1993). The rockfish is a viviparous, fiercely omnivorous fish that can reach a length of approximately $15-20 \mathrm{~cm}$; some individuals reach $30-40 \mathrm{~cm} . S$. marmoratus migrates within oceans, typically between feeding and spawning areas (Wourms et al., 1988).

S. marmoratus is highly valued as a marine food fish and has a high worldwide market demand. The rockfish is a commercially important near-shore species in Japan and China (Kita et al., 1996). Over the past few decades, the natural resource of the marbled rockfish has sharply decreased because of overfishing and heavy marine pollution. Therefore, $S$. marmoratus was classified as a national protected animal in the Marine Special Reserve of Zhejiang Province by the Chinese Government in 2006. To protect this natural resource and improve recovery strategies, studies examining the germplasm resources of $S$. marmoratus are urgently needed.

Microsatellite loci are powerful molecular markers that can be used to evaluate population genetic parameters, providing highly polymorphic and co-dominant information. It has been successfully used in genetic mapping, marker-assisted selection, population differentiation, and evolutionary studies ( $\mathrm{Li}, 2006)$. However, most of these studies in S. marmoratus were related to physiological and ecological aspects of the species (Mizue, 1959; Shiokawa, 1962; Watanabe, 2003; Yoko et al., 2006; Wang et al., 2005, 2009). Few microsatellite markers have been developed to examine genetic variation (Xu et al., 2010; Yin et al., 2012; Li et al., 2013). The number of appropriate polymorphic markers is insufficient to carry out phylogenetic and population genetic on this species. In this study, 11 microsatellite loci were developed for population genetic analysis of S. marmoratus.

\section{MATERIAL AND METHODS}

\section{Sample DNA extraction}

Thirty S. marmoratus individuals were collected from the sea near Xiamen in China. Organisms were preserved in alcohol. Genomic DNA was extracted from the muscle tissue of wild $S$. marmoratus individuals using the TIANamp Marine Animals DNA Kit (Tiangen, Beijing, China). Extracted genomic DNA was examined by electrophoresis on an agarose gel and stored at $-20^{\circ} \mathrm{C}$ until genotyping.

\section{Microsatellite-enriched library construction and primer design}

A microsatellite-enriched library was constructed according to the amplified fragment length polymorphism of sequences containing repeat protocol (Zane et al., 2002; Liao et al., 2007). Genomic DNA was digested using the restriction enzyme MseI (Fermentas, Vilnius, Lithuania) at $65^{\circ} \mathrm{C}$ for $3.5 \mathrm{~h}$. The digested fragments were ligated to synthesized $\mathrm{Mse}$ I adaptors (5'-ACGATGAGTCCTGAG-3'; B: 5'-TACTCAGGACTCAT-3') by T4 DNA ligase (Fermentas). Next, 2 biotinylated probes $\left[(\mathrm{GT})_{15},(\mathrm{CT})_{15}\right]$ and Streptavidin Magnetic Sphere ${ }^{\circledR}$ Paramagnetic Particles (Promega, Madison, WI, USA) were used to selectively enrich, capture, and 
wash the sample to obtain microsatellite-containing fragments. Fragments containing microsatellites were ligated to the pMD19-T vector (Takara, Shiga, Japan) and transformed into Escherichia coli DH5 $\alpha$ competent cells (Takara) by heat stimulation. Positive recombinant clones ranging from 500-1200 bp were selected for sequencing by Invitrogen (Carlsbad, CA, USA). Sequencing data were scanned using the SSRHunter v1.3 software (Li and Wan, 2005). Sequences containing microsatellite motifs and flanking regions were selected for polymerase chain reaction (PCR) primer design using Primer Premier 5.

\section{PCR amplification and genotyping}

The designed microsatellite primers were tested on the genomic DNA from 30 wild $S$. marmoratus individuals. PCR amplification was conducted in a $10-\mu \mathrm{L}$ total volume containing $50 \mathrm{ng}$ genomic DNA, 10X Taq buffer, $0.2 \mathrm{mM}$ dNTP, $2 \mathrm{mM} \mathrm{MgCl}$, $0.25 \mathrm{U}$ Taq DNA polymerase (Fermentas), $0.4 \mu \mathrm{M}$ forward primer, and $0.4 \mu \mathrm{M}$ reverse primer. The PCR conditions were $94^{\circ} \mathrm{C}$ for $5 \mathrm{~min}$, followed by 32 cycles at $94^{\circ} \mathrm{C}$ for $45 \mathrm{~s}$, annealing temperature for $45 \mathrm{~s}$, and elongation at $72^{\circ} \mathrm{C}$ for $45 \mathrm{~s}$, with a final extension at $72^{\circ} \mathrm{C}$ for $10 \mathrm{~min}$. PCR products were separated on $6 \%$ denaturing polyacrylamide gels by referring to 10-bp DNA ladder marker (Takara) and visualized by silver staining.

\section{Genetic data analysis}

The data matrix was analyzed to estimate the basic genetic information index using the POPGEN32 (v1.32) software (Yeh et al., 1999) and CERVUS3.0 (v3.0).

\section{RESULTS AND DISCUSSION}

For the 217 positive clones, 159 (73\%) contained microsatellite motif inserts, demonstrating that enrichment was highly effective. A total of 274 possessed microsatellite motifs (Table 1), of which $88.7 \%$ (243) were dinucleotide repeats. The sequences were divided into 3 categories following the classification rules developed by Weber (1990): 1) 226 perfect repeat sequences without interruptions in the runs of dinucleotides ( $87.6 \%$ of total);2) 24 imperfect repeat sequences with 1 or more interruptions in the run of repeats $(9.3 \%)$; and 3 ) 8 compound repeat sequences with adjacent tandem simple repeats of a different sequence (3.1\%). When classified using the repeat sequence type, all sequences contained dinucleotide repeats, of which the repeat number of 71 repeat sequences was 5-9, while the repeat number of $172 \mathrm{mi}-$ crosatellite sequences was higher than 10 .

Sixty-eight pairs of primers were designed for these clones using the Primer 5.0 software. Fifty-seven primer pairs containing the target regions were amplified by PCR amplification and tested in 4 S. marmoratus individuals. These primer pairs were initially tested on 30 S. marmoratus individuals; 11 primer pairs revealed polymorphic banding patterns. Characterizations of the 11 polymorphic loci are displayed in Table 2. The results showed that the number of alleles ranged from 2 to 7 , while the observed and expected heterozygosities ranged from 0.0333 to 0.9667 and from 0.0328 to 0.7675 using the POPGEN32 (v1.32) software. Two loci, Smd1-112 and Smd2-80, deviated from Hardy-Weinberg equilibrium (P $<0.00455$ ). The results calculated by CERVUS3.0 (v3.0) indicated that the polymorphism 
information content ranged from 0.032-0.751. These new microsatellite markers can be used to analyze the genetic structure of $S$. marmoratus and provide important genetic data regarding the conservation and recovery of $S$. marmoratus resources.

Table 1. Classification of microsatellite DNA sequences obtained in the study.

\begin{tabular}{llrr}
\hline Criterion & Category & No. of sequences & Percentage (\%) \\
\hline Nucleotides & 1 & 10 & 3.6 \\
& 2 & 243 & 88.7 \\
& 3 & 6 & 2.2 \\
& 4 & 9 & 3.3 \\
& 5 & 1 & 0.4 \\
Weber (1990) & 6 & 4 & 1.4 \\
& More than 7 & 1 & 0.4 \\
Repeat motif & Perfect & 226 & 87.6 \\
& Imperfect & 24 & 9.3 \\
& Compound & 8 & 3.1 \\
& Two bases $5 \leq \mathrm{n} \leq 9$ & 71 & 29.2 \\
\hline
\end{tabular}

Table 2. Characterization of 11 microsatellite loci isolated from Sebastiscus marmoratus (sample size $=30$ individuals).

\begin{tabular}{|c|c|c|c|c|c|c|c|c|c|c|}
\hline Locus ID & $\begin{array}{l}\text { GenBank } \\
\text { accession No. }\end{array}$ & Primer sequence ( $\left.5^{\prime}-3^{\prime}\right)$ & motif & $N_{\mathrm{A}}$ & $\begin{array}{l}\mathrm{Ta} \\
\left({ }^{\circ} \mathrm{C}\right)\end{array}$ & $\begin{array}{l}\text { Allele size } \\
\quad \text { (bp) }\end{array}$ & $H_{\mathrm{O}}$ & $H_{\mathrm{E}}$ & PIC & $P_{\mathrm{HWE}}$ \\
\hline $11-18$ & KF9 & $\begin{array}{l}\text { F: CCCCTGCTGTATTTGTTGC } \\
\text { R: GCCTCCCTTGTCAGTTGTTAT }\end{array}$ & $(\mathrm{AC})_{7}$ & 4 & 57.6 & 158 & 0.1667 & 0.1572 & 0.153 & 0.9 \\
\hline Smd1-19 & KF915969 & $\begin{array}{l}\text { F: CAGGCATAATGGATAGGT } \\
\text { R: CTGCTTGAGGGAGTGTTC }\end{array}$ & $(\mathrm{CA})_{6}(\mathrm{TACACA})_{3}$ & 3 & 53.2 & 136 & 0.2333 & 0.3561 & 0.319 & 0.02435 \\
\hline Smd1-49 & KF915970 & $\begin{array}{l}\text { F: GC } \\
\text { R: GC }\end{array}$ & $(\mathrm{CA})_{16}$ & 5 & 59.7 & $146-$ & 0.4643 & 0.3769 & 0.418 & 0.88675 \\
\hline Smd1-77 & KF915971 & $\begin{array}{l}F: A \\
\text { R: T }\end{array}$ & $(\mathrm{AC})_{8}$ & 4 & 48.8 & 188 & 0.7586 & 0.5713 & 0.517 & 0.00982 \\
\hline Smd1-86 & KF915972 & $\begin{array}{l}\text { F: TTGCGGAATAGAAGG } \\
\text { R: CAAACGCTGTGAAA }\end{array}$ & $(\mathrm{CT})_{5} \mathrm{TT}(\mathrm{CT})_{4} \mathrm{TT}(\mathrm{CT})_{7}$ & 6 & 53.2 & $135-176$ & 0.9667 & 0.7533 & 0.712 & 0.41905 \\
\hline Smd1-90 & KF915973 & $\begin{array}{l}\text { F: CCACAGTAAACTTTCCACG } \\
\text { R: CTCCAATCAACAAAACCAA }\end{array}$ & $(\mathrm{GA})_{14}$ & 5 & 53.2 & $170-190$ & 0.8000 & 0.6983 & 0.642 & 0.95006 \\
\hline Smd1-103 & KF915974 & $\begin{array}{l}\text { F: AACCCTCTAACCCTCAA } \\
\text { R: ATGTCATCGCACTTCCT }\end{array}$ & $(\mathrm{AC})_{5}$ & 4 & 57.6 & $165-177$ & 0.4000 & 0.4194 & 0.373 & 0.62094 \\
\hline Smd1-111 & KF915975 & $\begin{array}{l}\text { F: CCGACAGGTCAGAGAAAA } \\
\text { R: CGATAGAGACGGACAGCA }\end{array}$ & $(\mathrm{CA}$ & 2 & 53.2 & 21 & 0.0333 & 0.0328 & 0.032 & 1.0000 \\
\hline Smd1-112 & KF915976 & $\begin{array}{l}\text { F: TTCCTTGGGTCCTCAGCAATACA } \\
\text { R: TCCTGGCTACGGGGCAGATAACA }\end{array}$ & (CA) & 7 & 57.6 & $160-186$ & 0.5172 & 0.7675 & 0.751 & $0.00002 *$ \\
\hline Smd2-68 & KF915977 & $\begin{array}{l}\text { F: CAGACGGGAACATCACCATC } \\
\text { R: CAGAAACCGCACCTGACACT }\end{array}$ & $(\mathrm{GACAAG})_{3}$ & 3 & 44.5 & $242-264$ & 0.4000 & 0.4461 & 0.404 & 0.17588 \\
\hline $12-80$ & KF915978 & $\begin{array}{l}\text { F: TAAACAAACCAAACAAAG } \\
\text { R: GAAGAAACACAACAGAGC }\end{array}$ & $(\mathrm{TG})_{9} \mathrm{CG}(\mathrm{GT})_{38} \mathrm{AG}(\mathrm{TG})_{48}$ & 4 & 42.5 & 26 & 0.3448 & 0.4370 & 0.436 & $0.00452 *$ \\
\hline
\end{tabular}

$N_{\mathrm{A}}=$ number of polymorphic alleles; Ta $=$ annealing temperature; $H_{\mathrm{O}}=$ observed heterozygosity; $H_{\mathrm{E}}=$ expected heterozygosity; PIC = polymorphism information content; $P_{\mathrm{HWE}}=\mathrm{P}$ value for exact test for Hardy-Weinberg equilibrium (HWE) expectation test (adjusted $\mathrm{P}=0.00455)$. *Indicates significant departure from expected HardyWeinberg equilibrium.

\section{ACKNOWLEDGMENTS}

Research supported by the National Natural Science Foundation of China (\#31272668). 


\section{REFERENCES}

Kita J, Tsuchida S and Setoguma T (1996). Temperature preference and tolerance and oxygen consumption of the marbled rockfish, Sebastiscus marmoratus. Mar. Biol. 125: 467-471.

Li Q (2006). Development of microsatellite DNA markers and their applications in genetic studies of marine mollusks. $J$. Fish. Sci. China 3: 503-509.

Li Q and Wan JM (2005). SSRHunter: development of a local searching software for SSR sites. Yi Chuan. 27: 808-810.

Li QH, Li ZB, Dai G, Cao YY, et al. (2013). Isolation and characterization of eleven microsatellite loci in the marbled rockfish, Sebastiscus marmoratus (Scorpaenidae). Conserv. Genet. Resour. 6: 53-55.

Liao MJ, Yang GP, Wang XC, Wang DQ, et al. (2007). Development of microsatellite DNA markers of silver carp (Hypophthalmichthys molitrix) and their cross-species application in bighead carp (Aristichthys nobilis). Mol. Ecol. Notes 7: 95-99.

Mizue K (1959). Studies on a scorpaenous fish Sebastiscus marmoratus Cuvieret Valenciennes-IV. On the copulatory organ of the marine ovoviviparous teleost. Bull. Fac. Fish. Nagasaki Univ. 8: 80-83.

Shen SC (1993). Fishes of Taiwan. National Taiwan University Press, Taipei.

Shiokawa T (1962). Growth and maturity of the common rockfish, Sebastiscus marmoratus Cuvieret Valenciennes. Rec. Oceanogr. Wks. Jap. 6: 91-102.

Wang CG, Zheng RH, Ding X, Zuo ZH, et al. (2005). Effect of tributyltin, benzo-pyrene, and their mixture on the hepatic monooxygenase system in Sebastiscus marmoratus. Bull. Environ. Contam. Toxicol. 75: 1214-1219.

Wang YQ, Wang CG, Zhang JL, Chen YX, et al. (2009). DNA hypomethylation induced by tributyltin, triphenyltin, and a mixture of these in Sebastiscus marmoratus liver. Aquat. Toxicol. 95: 93-98.

Watanabe S (2003). Age and growth of scorpion fish, Sebastiscus marmoratus in coastal waters off Oseto and Kuchinotsu, Nagasaki. Bull. Nagasaki Pref. Inst. Fish. 28: 1-7.

Weber JL (1990). Informativeness of human (dC-dA)n. (dG-dT)n polymorphisms. Genomics. 7: 524-530.

Wourms JP, Grove BD and Lombardi J (1988). The maternal-embryonic relationship in viviparous fishes. Vol. 11B of Fish Physiology (Hoar WS and Randall DJ, eds.). Academic Press, San Diego, 1-134.

Xu TJ, Quan XQ, Yue N, Zhao KC, et al. (2010). A first set of polymorphic microsatellite loci from the marbled rockfish, Sebastiscus marmoratus. Biochem Genet. 48: 680-683.

Yeh FC, Yang RC and Boyle T (1999). POPGENE version 1.31: Microsoft Windows-Based Freeware for Population Genetic Analysis. University of Alberta and Centre for International Forestry Research, Edmonton. Available at [http://www.ualberta.ca/ fyeh/popgene_download.html]. Accessed April 20, 2011.

Yin LN, Zhang H, Yanagimoto T and Gao TX (2012). Isolation and characterization of nine polymorphic microsatellite markers of the marbled rockfish Sebastiscus marmoratus (Scorpaeniformes, Scorpaenidae). Russ. J. Genet. 48: 12641266.

Yoko M, Yasushi K, Atsushi H, Yoshitaka S, et al. (2006). Evaluation of larval quality of viviparous scorpionfish Sebastiscus marmoratus. Fish. Sci. 72: 948-954.

Zane L, Bargelloni L and Patarnello T (2002). Strategies for microsatellite isolation: a review. Mol. Ecol. 11: 1-16. 